\title{
PENINGKATAN HASIL TES FISIK ATLET PORPROV KOTA SURAKARTA TAHUN 2016 DAN 2017
}

\author{
Djoko Nugroho \\ Universitas Sebelas Maret Surakarta
}

\begin{abstract}
Abstrak
Tes ini bertujuan untuk mengetahui peningkatan kemampuan kondisi fisik atlet porprov kota surakarta. Tes yang digunakan adalah tes kemampuan kondisi fisik secara umum yang meliputi kekuatan, daya tahan, kecepatan, kelentukan dan daya ledak.

Untuk mengetahui kekuatan otot atlet yang digunakan adalah tes kekuatan peras tangan/Grip strength. Untuk mengetahui daya tahan otot dipergunakan tes daya tahan otot lengan dan bahu dengan menggunakan push up, daya tahan otot perut dengan menggunakan sit up dan daya tahan kardiorespiratori dengan menggunakan tes lari multi tahap (Multi-Stage Fitness Test). Tes kecepatan menggunakan lari sprint $40 \mathrm{~m}$. Tes pengukuran yang di pakai untuk mengetahui daya ledak otot tungkai atlet adalah vertikal jump. Dan tes yang dipakai untuk mengetahui kelentukan otot punggung dengan menggunakan sit and reach test.

Dari 41 cabor yang ada data yang diambil dari hasil tes yang telah diselenggarakan. Data yang terkumpul merupakan data deskriptif yang kemudian dikonversi menjadi data kuantitatif dengan indeks penilaian yang telah ditentukan sesuai dengan pencapaian indikator dan sub indikator pada tiap item
\end{abstract}

Keywords : Tes Kondisi Fisik Atlet Porprov Surakarta

\section{PENDAHULUAN}

Kemampuan atlet dapat dilihat dari hasil tes dan pengukuran yang dilakukan secara periodik dan terus menerus sehingga penigkatan kemampuan kondisi fisik akan diikuti oleh peningkatan prestasi atlet itu sendiri. Tes adalah suatu cara untuk mengadakan penilaian yang berbentuk suatu tugas atau serangkaian tugas yang harus dikerjakan oleh seseorang atau kelompok sehingga menghasilkan suatu nilai tentang tingkah laku atau prestasi anak tersebut (Sumartana, 1986). Menurut Johnson dan Nelson (1996) tes merupakan alat pengumpul data yang dapat digunakan untuk kepentingan evaluasi. Selanjutnya Kirkendall, dkk (1980) menyatakan bahwa: "test is an instrument used to gain information about individuals or objects". Apabila diaplikasikan dalam konteks kemampuan fisiologis, maka pengertian tes dapat bermakna sebagai alat ukur yang digunakan untuk memperoleh data kemampuan fisiologis atlet.

Syarat suatu tes harus obyektif, valid, dan reliabel, obyektif berarti hasil tes betul-betul menunjukkan kemampuan sebenarnya dari kemampuan atlet. Validitas berasal dari kata valid yang salah satu artinya sahih (Echols dan Shadily, 2000). Suatu tes dikatakan valid bilamana tes tersebut benar-benar menggambarkan kesahihan aspek yang hendak diukur. Validitas 
menunjukkan suatu derajat atau taraf tinggi, sedang atau rendah, bukan valid atau tidak valid. Reliabilitas berasal dari kata reliabel yang artinya ajek. Suatu tes dikatakan reliabel bilamana tes tersebut dapat memberikan hasil yang ajek atau konsisten terhadap hasil pengukurannya walaupun dilakukan secara berulang-ulang. Obyektivitas suatu alat ukur diartikan, keajegan hasil suatu tes yang diperoleh dari dua atau lebih pengetes atau tester. Pengertian keajegan dalam hal ini setara dengan kata keseragaman. Jadi bila seorang atlet melakukan tes chees pass, dan hasi! Lemparan depan dada dalam bola basket diukur oleh dua atau lebih tester dan hasil pengukurannya ada keseragaman antara tester satu dan lairmya, maka hasil pengukuran itu dikatakan obyektif.

Kemampuan atlet porprov kota Surakarta sesaui dengan data dari KONI kota Surakarta selalu dievaluasi dengan mengadakan tes secara berkala setiap tahunnya, dari data yang terkumpul akan di jadikan bahan evaluasi secara menyeluruh.Tujuan evaluasi untuk peningkatan kemampuan fisik atlet dalam pencapaian prestasi puncak sesuai target yang sudah ditentukan. Program pembinaan atlet porprov kota Surakarta dilaksanakan secara periodik, berjenjang, sistematis dan berkelanjutan dimaksudkan untuk meningkatkan prestasi para atlet melalui program latihan yang didukung dengan penerapan IPTEK Olahraga dan Kompetisi yang terarah, sesuai dengan periodisasi latihan dan tingkat perkembangan fisik serta psikologisnya.

Tes kemampuan fisik atlet kota Surakarta dilakukan berdasarkan pada tes kemampuan fisik secara umum (General Fitness Test) antara lain meliputi ;

1. Kekuatan (Strength)

2. Daya tahan (Endurance)

3. Kecepatan (Speed)

4. Kelentukan (Flexibility)

5. Daya ledak (Explosive Power)

Sedangkan untuk jenis tes yang dilakukan untuk mengetahui kemampuan fisik atlet porprov kota Surakarta tahun 2016 dan 2017 adalah ;

\section{Kekuatan (Strength)}

Kekuatan merupakan salah satu komponen kondisi fisik yang sangat diperlukan pada sebagian besar cabang olahraga karena sangat mendukung dalam mempertahankan kualitas penampilan atlet. Kekuatan juga merupakan salah satu unsur kemampuan gerak sebagai fundamen dominan pada beberapa cabang olahraga. Kekuatan merupakan komponen kondisi fisik yang menyangkut masalah kemampuan seseorang atlet pada saat mempergunakan ototototnya, dan menerima beban dalam waktu kerja tertentu.

Definisi kekuatan menurut Pate (1984) adalah tenaga yang dapat dikerahkan sekelompok otot pada usaha tunggal yang maksimal. Kemampuan kontraksi otot maksimal dapat dikerahkan melalui suatu kontraksi yaitu secara isometrik, isokinetik, dan isotonik. Selanjutnya Roberts (2000) mendefinisikan kekuatan yaitu "strength is the maximum 
muscular force which can be exerted in a single effort". Frank (1998) juga mendefinisikan kekuatan sebagai "muscular strength is the ability of the muscle to generate the maximum amount of force". Suharno (1992) mendefinisikan kekuatan yaitu kemampuan otot untuk dapat mengatasi tahanan/beban, menahan atau memindahkan beban dalam menjalankan aktivitas olahraga. Dari definisi tersebut di atas dapat disimpulkan bahwa kekuatan adalah kemampuan otot untuk dapat mengatasi tahanan/beban, menahan atau memindahkan beban dalam menjalankan aktivitas olahraga. Untuk mengetahui kekuatan otot atlet porprov kota Surakarta yang digunakan tes kekuatan peras tangan / Grip strength. Petunjuk pelaksanaan tes, alat yang dipergunakan dan normanya adalah sebagai berikut :

Tujuan: untuk mengetahui kemampuan peras tangan atlet

Alat : hand grip dynamometer

Pelaksanaan: gunakan pegangan hand grip untuk mengukur kekuatan peras tangan. Atlet mencengkeram alat sekuat-kuatnya. Atlet diberi kesempatan untuk melakukan 3 kali tes, ambil skor tertinggi $(\mathrm{kg})$ sebagai hasil akhir.

Skor : Nilai tertinggi dari hasil tes.

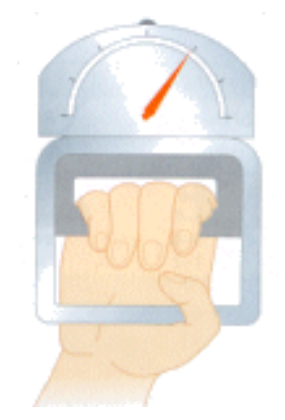

Gambar 1. Hand Grip Dynamometer

Normatif data untuk grip strength secara nasional untuk anak usia 16-19 tahun (Davis et al, 2000):

\begin{tabular}{l|l|l|l|l|l|l|}
\hline Gender & Excellent & Good & Average & Fair & Poor \\
\hline Male & $>56$ & $51-56$ & $45-50$ & $39-44$ & $<39$ \\
\hline Female & $>36$ & $31-36$ & $25-30$ & $19-24$ & $<19$ \\
\hline
\end{tabular}

\section{Daya Tahan (Endurance)}

Daya tahan merupakan salah satu komponen kondisi fisik yang penting dalam olahraga namun tentunya tidak lepas dari komponen lainnya seperti kekuatan, kecepatan dan 
kelentukan. Menurut Suharno (1992) daya tahan adalah kemampuan organ atlet untuk melawan kelelahan yang timbul saat menjalankan aktivitas olahraga dalam waktu lama.

Selanjutnya Bompa (1994) mengklasifikasikan daya tahan menjadi dua golongan yaitu daya tahan umum (general endurance) dan daya tahan khusus (specific endurance). Sedangkan ditinjau dari segi waktu yang digunakan dalam aktivitas daya tahan dibagi menjadi tiga yaitu 1) daya tahan dengan waktu yang panjang (lebih dari 8 menit), 2) daya tahan dengan waktu sedang (2 - 6 menit, 3) daya tahan dengan waktu pendek (42 detik - 2 menit).

Namun Sajoto (1988) membedakan daya tahan menjadi dua golongan yaitu daya tahan otot lokal (local endurance) dan daya tahan umum (cardiorespiratory endurance). Daya tahan otot lokal yaitu kemampuan seseorang dalam mempergunakan sekelompok otot lokal dalam waktu yang cukup lama. Daya tahan umum yaitu kemampuan seseorang dalam mempergunakan sistem jantung, pernapasan dan peredaran darah secara efektif dan efisien dalam menjalankan kerja terus menerus. Daya tahan umum ini melibatkan kontraksi sejumlah otot-otot besar dengan intensitas tinggi dalam waktu yang cukup lama.

Untuk mengetahui daya tahan otot atlet porprov kota Surakarta dipergunakan tes daya tahan otot lengan dan bahu dengan menggunakan push ups, daya tahan otot perut dengan menggunakan sit ups dan daya tahan kardiorespiratori dengan menggunakan tes lari multi tahap (Multi-Stage Fitness Test).

Tujuan, alat, petunujuk pelaksanaan tes dan norma yang dipergunakan adalah sebagai berikut:

\section{a. Daya Tahan Otot Lengan dan Bahu/Push Up}

Tujuan: untuk mengetahui kemampuan kekuatan daya tahan otot tubuh bagian atas (ekstensor)

Alat : permukaan datar, matras

Pelaksanaan: untuk atlet laki-laki dimulai dengan telungkup di atas matras, kedua tangan selebar bahu dan lurus (full extention) seperti pada Gambar 1. Turunkan badan sampai siku membentuk sudut $90^{\circ}$ seperti pada Gambar 2a. Kemudian kembali ke posisi awal dengan kedua tangan full extention. Gerakan dilakukan secara terus menerus tanpa istirahat. Atlet melakukan gerakan push ups sebanyak mungkin. Catat jumlah total gerakan yang dilakukan oleh atlet dengan benar.

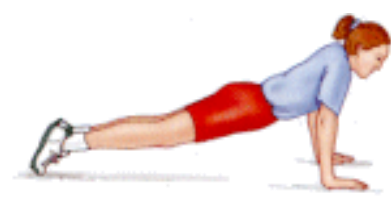

Gambar 1.

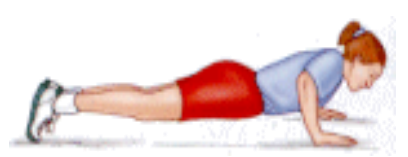

Gambar 2.

Atlet wanita cenderung memiliki kekuatan relatif yang kurang untuk tubuh bagian atas, oleh karena itu dapat menggunakan posisi yang berbeda untuk mengetahui kekuatan daya tahan tubuh bagian atas. Atlet telungkup di atas matras, dengan kedua tangan selebar bahu, posisi lutut ditekuk dan tangan full extention seperti Gambar 3. Turunkan tubuh bagian atas sampai 
siku mencapai sudut $90^{\circ}$ seperti Gambar 4. Kembali ke posisi semula dengan tangan full extention. Atlet melakukan gerakan ini terus menerus tanpa istirahat. Atlet melakukan tes push ups sebanyak mungkin. Catat jumlah total gerakan yang dilakukan atlet dengan benar.

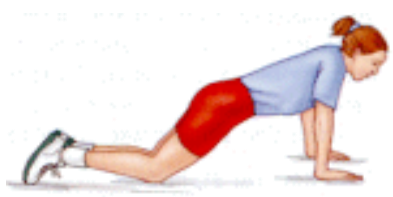

Gambar 3.

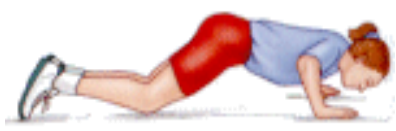

Gambar 4.

Skor : jumlah total gerakan benar yang dilakukan oleh atlet dipakai sebagai hasil tes push up.

Normatif data untuk modifikasi push up (McArdle et al, 2000)

\begin{tabular}{|c|c|c|c|c|c|}
\hline \multicolumn{1}{|c|}{ Age } & Excellent & Good & Average & Fair & Poor \\
\hline $20-29$ & $>48$ & $34-38$ & $17-33$ & $6-16$ & $<6$ \\
\hline $30-39$ & $>39$ & $25-39$ & $12-24$ & $4-11$ & $<4$ \\
\hline $40-49$ & $>34$ & $20-34$ & $8-19$ & $3-7$ & $<3$ \\
\hline $50-59$ & $>29$ & $15-29$ & $6-14$ & $2-5$ & $<2$ \\
\hline $60+$ & $>19$ & $5-19$ & $3-4$ & $1-2$ & $<1$ \\
\hline
\end{tabular}

\section{b. Daya Tahan Otot Perut/Sit Ups}

Tujuan : mengukur kemampuan komponen daya tahan otot perut

Alat : matras

Pelaksanaan: orang coba tidur terlentang, kedua tangan saling berkaitan di belakang kepala, kedua kaki dilipat sehingga membentuk sudut $90^{\circ}$, seorang pembantu memegang erat-erat kedua pergelangan kaki orang coba dan menekannya pada saat orang coba bangun. Orang coba berusaha bangun sehingga berada dalam sikap duduk dan kedua siku dikenakan pada kedua lutut dan kemudian kembali ke sikap semula. Lakukan gerakan ini secara berulangulang dan kontinyu, sampai orang coba tak mampu mengangkat badannya lagi. Perhatikan agar sikap tungkai selalu membentuk sudut $90^{\circ}$ pada waktu melakukan sit ups.

Skor : jumlah gerak sit ups yang betul dihitung sebagai hasil akhir 


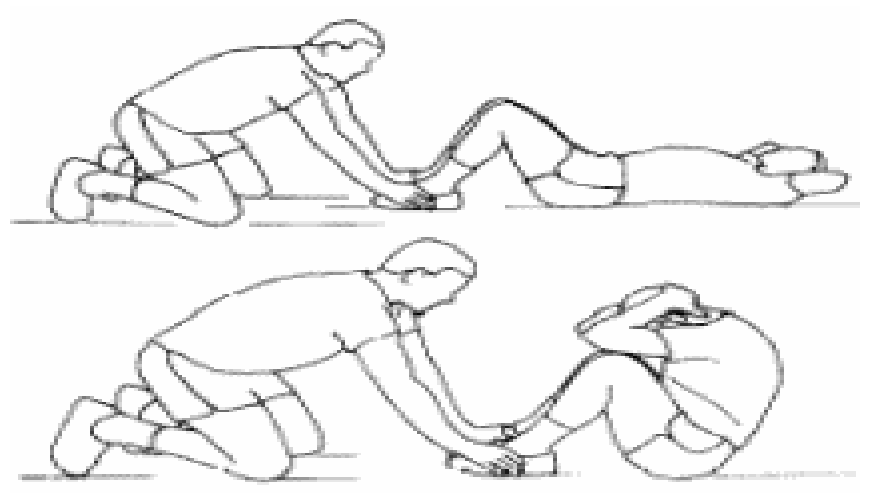

Normatif data sit up dari Davis B. Et.al,2000 adalah sebagai berikut :

\begin{tabular}{|l|c|c|c|}
\multicolumn{1}{|c|}{ Norma Penilaian Sit-Up (Jumlah ulangan) } \\
\hline Kategori & Putra & Putri & Konversi Nilai \\
\hline Saikgat Baik & $>30$ & $>25$ & 10 \\
\hline Sedang & $30-26$ & $25-21$ & 8 \\
\hline Kurang & $25-20$ & $20-15$ & 6 \\
\hline Sangat Kurang & $19-17$ & $14-9$ & 4 \\
\hline
\end{tabular}

(Sumber. Davis B. et.al, 2000)

\section{c. Multi-Stage Fitness Test (Bleep Test / Beep Test)}

Tujuan: untuk mengetahui kemampuan daya tahan kardiovaskuler (VO2max) atlet dan untuk mendapatkan prediksi VO2max atlet. Tes ini cocok untuk atlet cabang olahraga permainan, sebaiknya tidak digunakan untuk atlet cabang olahraga dayung, balap sepeda

Alat : permukaan datar yang tidak licin dengan panjang mininal $20 \mathrm{~m}$, meteran pita $30 \mathrm{~m}$, cones, CD MSFT, CD/Tape player, lembar form test

Pelaksanaan: ukur panjang lintasan $20 \mathrm{~m}$ dan tandai pada masing-masing sisi dengan cones. Atlet pemasan sebelum melakukan tes. Putar CD/Tape MSFT, kemudian atlet menempatkan salah satu kaki pada atau di luar garis tanda $20 \mathrm{~m}$ pada saat akan jalan/lari dan pada setiap akhir shuttle. Atlet mengikuti bunyi "beep" sebagai tanda awal/akhir setiap shuttle. Jika atlet sampai pada garis sebelum bunyi "beep" maka atlet harus menunggu bunyi tersebut kemudian berlari lagi. Atlet harus berusaha berlari mengikuti tanda "beeb" untuk mencapai level dan shuttle setinggi-tingginya. Jika atlet gagal sebanyak 2 kali berturut-turut tidak sampai pada garis setelah bunyi "beep" maka atlet dinyatakan diskualifikasi dan disuruh berhenti tes. Petugas pencatat skor mencatat hasil level dan shuttle yang telah diperoleh atlet. Setelah tes atlet melakukan pendinginan

Skor : skor diperoleh dari hasil level dan shuttle tertinggi yang berhasil ditempuh oleh atlet, kemudian prediksi VO2max bisa dilihat pada tabel MSFT. 
Normatif data untuk Multi-Stage Fitness Test:

Putra

\begin{tabular}{|c|c|c|c|c|c|}
\hline Age & Excellent & Above Average & Average & Below Average & Poor \\
\hline $14-16$ & L12 S7 & L11 S2 & L8 S9 & L7 S1 & $<$ L6 S6 \\
\hline $17-20$ & L12 S12 & L11 S6 & L9 S2 & L7 S6 & $<\mathrm{L} 7 \mathrm{~S} 3$ \\
\hline $21-30$ & L12 S12 & L11 S7 & L9 S3 & L7 S8 & $<$ L7 S5 \\
\hline $31-40$ & L11 S7 & L10 S4 & L6 S10 & L6 S7 & $<\mathrm{L} 6 \mathrm{~S} 4$ \\
\hline $41-50$ & L10 S4 & L9 S4 & L6 S9 & L5 S9 & $<$ L5 S2 \\
\hline
\end{tabular}

Putri

\begin{tabular}{|c|c|c|c|c|c|}
\hline Age & Excellent & Above Average & Average & Below Average & Poor \\
\hline $14-16$ & L10 S9 & L9 S1 & L6 S7 & L5 S1 & $<$ L4 S7 \\
\hline $17-20$ & L10 S11 & L9 S3 & L6 S8 & L5 S2 & $<$ L4 S9 \\
\hline $21-30$ & L10 S8 & L9 S2 & L6 S6 & L5 S1 & $<$ L4 S9 \\
\hline $31-40$ & L10 S4 & L8 S7 & L6 S3 & L4 S6 & $<$ L4 S5 \\
\hline $41-50$ & L9 S9 & L7 S2 & L5 S7 & L4 S2 & $<$ L4 S1 \\
\hline
\end{tabular}

\section{Kecepatan (Speed)}

Kecepatan (speed) merupakan salah satu komponen kondisi fisik yang penting dalam aktivitas olahraga guna mencapai prestasi yang maksimal. Hal ini terutama diperlukan pada cabang olahraga yang memerlukan suatu gerakan yang menuntut gerak cepat dan selalu bergerak ke berbagai arah (posisi) dengan cepat. Kecepatan merupakan kemampuan untuk melaksanakan gerak dengan cepat. Definisi kecepatan menurut Suharno (1992) adalah kemampuan atlet untuk melakukan gerakan-gerakan yang sejenis secara berturut-turut dalam waktu sesingkat-singkatnya. Selanjutnya Sajoto (1988) juga mengemukakan bahwa kecepatan adalah kemampuan seseorang dalam melakukan gerakan berkesinambungan dalam bentuk yang sama dalam waktu sesingkat-singkatnya. Dari definisi tersebut di atas dapat disimpulkan bahwa kecepatan adalah kemampuan dalam melakukan gerakan yang sejenis secara berturut- 
turut dalam waktu yang sesingkat-singkatnya atau kemampuan untuk menempuh satu jarak dalam waktu yang sesingkat-singkatnya.

Suharno (1992) membedakan kecepatan menjadi tiga macam yaitu kecepatan reaksi, kecepatan sprint, dan kecepatan bergerak. Kecepatan reaksi adalah waktu antara rangsangan dan jawaban gerak pertama. Kecepatan sprint adalah kemampuan atlet untuk menempuh suatu jarak dalam waktu yang sesingkat-singkatnya. Kecepatan bergerak adalah kemampuan atlet bergerak secepat mungkin dalam satu gerak yang ditandai waktu antara gerak permulaan dengan gerak akhir.

Norma Tes Lari Kecepatan 40 meter(R. Lumintuarso, 2001. Pemandu Bakat Atletik.)

\begin{tabular}{|c|c|c|}
\hline Putri & Status & Putra \\
\hline$<5,4 \mathrm{det}$ & Sangat baik & $<5,2 \mathrm{det}$ \\
$5,4-6,6 \mathrm{det}$ & Baik & $5,2-6,0 \mathrm{det}$ \\
$6,6-7,2 \mathrm{det}$ & Cukup & $6,0-6,4 \mathrm{det}$ \\
$7,2-9,0 \mathrm{det}$ & Kurang & $6,4-7,6 \mathrm{det}$ \\
$>9,0 \mathrm{det}$ & Kurang sekali & $>7,6 \mathrm{det}$ \\
\hline
\end{tabular}

\section{Daya Ledak (Explosive Power)}

Daya ledak merupakan komponen kondisi fisik yang sangat diperlukan atlet dalam melakukan gerakan dengan intensitas yang sangat tinggi. Selain itu, kemampuan daya ledak atlet merupakan hal yang sangat penting dalam pembinaan atlet untuk mencapai prestasi yang optimal. Daya ledak merupakan kemampuan daya maksimal dalam waktu tercepat. Kemampuan daya ledak otot sangat diperlukan untuk cabang olahraga lempar, tolak, lompat, dan lain-lain.

Tes pengukuran yang di pakai untuk mengetahui daya ledak otot tungkai atlet porprov Surakarta adalah vertikal jump. Tujuan, alat, petunujuk pelaksanaan tes dan norma yang dipergunakan adalah sebagai berikut:

\section{Daya Ledak Otot Tungkai (Vertical Jump)}

Tujuan: mengukur kemampuan komponen daya ledak otot tungkai secara vertikal Alat : bidang datar, papan vertical jump

Pelaksanaan: orang coba berdiri menghadap dindiing dengan salah satu lengan diluruskan ke atas. Kemudian orang coba berdiri dengan bagian samping tubuhnya ke arah tembok, dan salah satu lengan yang terdekat dengan tembok lurus ke atas, kemudian mengambil sikap jongkok sehingga lututnya membentuk sudut $\pm 45^{\circ}$, setelah itu orang coba berusaha melompat ke atas setinggi mungkin. Pada saat titik tertinggi dari lompatan itu segera menyentuhkan 
ujung jari dari salah satu tangannya pada papan ukuran kemudian mendarat dengan kedua kaki. Orang coba diberi kesempatan sebanyak 3 kali.

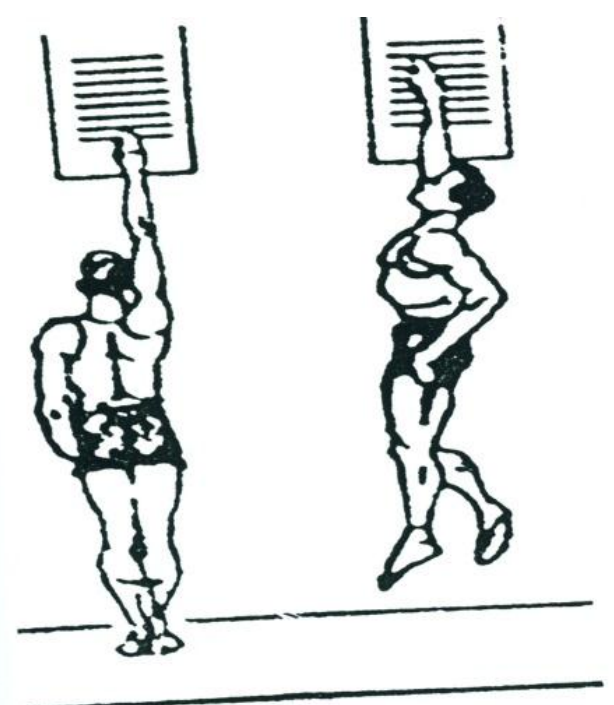

Skor: selisih yang terbesar antara tinggi jangkauan sesudah melompat dengan tinggi jangkauan sebelum melompat yang diukur dalam cm dipakai sebagai hasil akhir.

Norma Penilaian Vertical Jump (Practical Measurement for Evaluation in Physical education, Barry.L. Jhonson, 1979)

\begin{tabular}{|c|c|c|}
\hline \multicolumn{2}{|c|}{ JARAK LONCATAN (kerja) } & \multirow{2}{*}{ KLASIFIKASI } \\
\cline { 1 - 2 } PRIA & WANITA & Baik Sekali \\
\hline$>301$ & $>134$ & Baik \\
\hline $240-300$ & $108-133$ & Cukup \\
\hline $115-239$ & $55-107$ & Kurang \\
\hline $54-114$ & $30-54$ & Kurang Sekali \\
\hline $0-53$ & $0-29$ & \\
\hline
\end{tabular}

\section{Kelentukan (Flexibility)}

Kelentukan merupakan salah satu komponen kondisi fisik yang sangat diperlukan atlet khususnya cabang olahraga senam. Kelentukan yaitu kemampuan seseorang melakukan 
bermacam-macam kegiatan fisik yang ditentukan oleh seluruh anggota tubuh atau sendi-sendi tertentu. Kelentukan ditentukan baik hal fisiologis maupun mekanis. Dalam melakukan suatu ketangkasan seseorang yang lebih fleksibel (lentuk) mengeluarkan energi lebih sedikit disbanding seseorang yang kurang lentuk.

Tes yang dipakai atlet kota Surakarta untuk mengetahui kelentukan adalah kelentukan otot punggung dengan menggunakan sit and reach test, flexiometer. Tujuan tes untuk mengukur kemampuan komponen fleksibilitas otot punggung

Alat : Flexiometer

Pelaksanaan: orang coba berdiri tegak di atas alat ukur dengan kedua kaki rapat dan kedua ujung ibu jari kaki rata dengan pinggir alat ukur. Badan dibungkukkan ke bawah, kedua tangan lurus. Renggutkan badan ke bawah perlahan-lahan sejauh mungkin, kedua tangan menelusuri alat ukur dan berhenti pada jangkauan terjauh.

Skor : jarak jangkauan terjauh yang dapat dicapai oleh orang coba, yang diukur dalam $\mathrm{cm}$.

\section{PEMBAHASAN}

Tabel hasil tes fisik Atlet Porprov kota Surakarta tahun 2016-2017

\begin{tabular}{|c|c|c|c|c|c|c|c|c|c|c|c|c|c|c|c|c|c|c|c|c|}
\hline \multirow[b]{2}{*}{ No } & \multirow[b]{2}{*}{ CABOR } & \multirow[b]{2}{*}{ 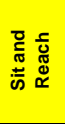 } & \multirow[b]{2}{*}{ 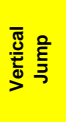 } & \multirow[b]{2}{*}{$\frac{\text { Sิ }}{\stackrel{5}{5}}$} & \multirow[b]{2}{*}{$\begin{array}{l}\frac{0}{2} \\
\frac{5}{5} \\
3 \\
0\end{array}$} & \multirow[b]{2}{*}{ 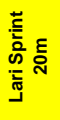 } & \multirow[b]{2}{*}{ 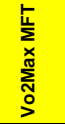 } & \multirow[b]{2}{*}{ 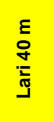 } & \multirow[b]{2}{*}{ 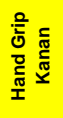 } & \multirow[b]{2}{*}{ 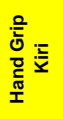 } & \multirow[b]{2}{*}{ 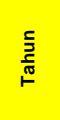 } & \multicolumn{9}{|c|}{ Prosentase Tingkat Keberhasilan di Tahun 2017} \\
\hline & & & & & & & & & & & & 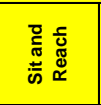 & 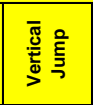 & $\frac{2}{\stackrel{2}{5}}$ & $\begin{array}{l}\frac{2}{2} \\
\frac{5}{n} \\
\frac{n}{2}\end{array}$ & 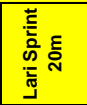 & 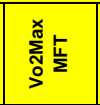 & $\begin{array}{c}\mathbf{E} \\
\stackrel{9}{+} \\
\stackrel{5}{ \pm} \\
\end{array}$ & 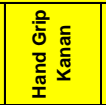 & 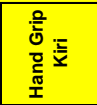 \\
\hline 1 & Anggar & \begin{tabular}{|l|}
42.22 \\
42.35
\end{tabular} & \begin{tabular}{|l|}
52.44 \\
40.92 \\
\end{tabular} & $\begin{array}{l}41.89 \\
43.23\end{array}$ & \begin{tabular}{|l|}
41.44 \\
33.38
\end{tabular} & 5.45 & $\begin{array}{l}35.33 \\
35.21\end{array}$ & 7.26 & 34.81 & 29.47 & $\begin{array}{l}2016 \\
2017\end{array}$ & meningkat & menurun & meningkat & menurun & menurun & menurun & meningkat & meningkat & meningkat \\
\hline 2 & Aeromodeling & $\begin{array}{l}35.90 \\
38.25\end{array}$ & $\begin{array}{l}53.00 \\
48.50\end{array}$ & $\begin{array}{l}30.60 \\
27.00\end{array}$ & $\begin{array}{l}12.60 \\
18.33 \\
\end{array}$ & 3.72 & $\begin{array}{l}29.86 \\
28.87\end{array}$ & 7.26 & 31.93 & 30.15 & $\frac{2016}{2017}$ & menurun & menurun & menurun & meningkat & menurun & menurun & meningkat & meningkat & meningkat \\
\hline 3 & PAPSI & 36.23 & 46.05 & 34.47 & 23.15 & & 22.63 & & & & $\frac{2016}{2017}$ & menurun & menurun & menurun & meningkat & sama & menurun & sama & sama & sama \\
\hline 4 & Atletik & \begin{tabular}{|l|}
43.59 \\
44.70 \\
\end{tabular} & \begin{tabular}{|l|}
67.13 \\
52.80
\end{tabular} & $\begin{array}{l}51.94 \\
49.40\end{array}$ & $\begin{array}{l}32.06 \\
34.00 \\
\end{array}$ & 3.21 & \begin{tabular}{|l|}
47.49 \\
37.32 \\
\end{tabular} & 6.09 & 23.70 & 23.04 & $\begin{array}{l}2016 \\
2017\end{array}$ & meningkat & menurun & menurun & meningkat & menurun & menurun & sama & sama & sama \\
\hline 5 & Balap Motor & 43.75 & 65.00 & 49.00 & 31.00 & 3.43 & 39.55 & & & & $\begin{array}{l}2016 \\
2017\end{array}$ & menurun & menurun & menurun & menurun & menurun & menurun & sama & sama & sama \\
\hline 6 & \begin{tabular}{|l|} 
Balap \\
Sepeda
\end{tabular} & \begin{tabular}{|l|}
40.50 \\
41.92 \\
\end{tabular} & \begin{tabular}{|l|}
46.67 \\
50.83 \\
\end{tabular} & $\begin{array}{l}41.89 \\
49.33 \\
\end{array}$ & \begin{tabular}{|l|}
41.22 \\
42.00 \\
\end{tabular} & 4.06 & \begin{tabular}{|l|}
32.11 \\
46.47 \\
\end{tabular} & 6.49 & 38.44 & 33.56 & $\begin{array}{l}2016 \\
2017 \\
\end{array}$ & meningkat & menigkat & meningkat & meningkat & menurun & meningkat & meningkat & meningkat & meningkat \\
\hline 7 & Billiard & 40.60 & 53.75 & 41.70 & 29.30 & 3.60 & 35.54 & & & & $\begin{array}{l}2016 \\
2017\end{array}$ & menurun & menurun & menurun & menurun & menurun & menurun & sama & sama & sama \\
\hline 8 & Basket & \begin{tabular}{|l|}
33.38 \\
35.00 \\
\end{tabular} & $\begin{array}{l}54.05 \\
44.67 \\
\end{array}$ & $\begin{array}{l}39.65 \\
43.78 \\
\end{array}$ & $\begin{array}{l}44.65 \\
34.44 \\
\end{array}$ & 3.50 & $\begin{array}{l}37.51 \\
37.57 \\
\end{array}$ & 6.87 & 30.09 & 30.93 & $\begin{array}{l}2016 \\
2017\end{array}$ & meningkat & menurun & meningkat & menurun & menurun & meningkat & meningkat & meningkat & meningkat \\
\hline 9 & Bola Voli & 38.37 & 60.65 & 43.92 & 27.65 & 3.42 & 34.17 & & & & $\begin{array}{l}2016 \\
2017 \\
\end{array}$ & menurun & menurun & menurun & menurun & menurun & menurun & sama & sama & sama \\
\hline 10 & Bridge & $\begin{array}{l}38.56 \\
32.75 \\
\end{array}$ & $\begin{array}{l}59.75 \\
39.50 \\
\end{array}$ & $\begin{array}{l}43.50 \\
26.00 \\
\end{array}$ & $\begin{array}{l}26.63 \\
16.00 \\
\end{array}$ & 3.51 & $\begin{array}{l}32.59 \\
28.70 \\
\end{array}$ & 7.95 & 28.13 & 26.38 & $\begin{array}{l}2016 \\
2017 \\
\end{array}$ & menurun & menurun & menurun & menurun & menurun & menurun & meningkat & meningkat & meningkat \\
\hline 11 & Bulutangkis & 48.10 & 57.60 & 46.80 & 28.60 & 16.88 & 21.78 & & & & $\begin{array}{l}2016 \\
2017\end{array}$ & menurun & menurun & menurun & menurun & menurun & menurun & sama & sama & sama \\
\hline 12 & Catur & $\begin{array}{c}0.00 \\
36.00 \\
\end{array}$ & \begin{tabular}{|l|}
0.00 \\
40.18 \\
\end{tabular} & $\begin{array}{r}0.00 \\
33.45 \\
\end{array}$ & \begin{tabular}{|c|}
0.00 \\
23.91 \\
\end{tabular} & 0.00 & \begin{tabular}{|l|}
26.14 \\
26.41 \\
\end{tabular} & 8.12 & 28.68 & 26.10 & $\begin{array}{l}2016 \\
2017 \\
\end{array}$ & meningkat & meningkat & meningkat & meningkat & sama & meningkat & sama & sama & sama \\
\hline 13 & Dansa & 44.67 & 60.42 & 50.17 & 36.83 & 11.68 & 37.05 & & & & $\begin{array}{l}2016 \\
2017\end{array}$ & menurun & menurun & menurun & menurun & menurun & menurun & sama & sama & sama \\
\hline 14 & Drumband & 40.14 & 48.28 & 34.89 & 37.78 & & 29.20 & & & & $\begin{array}{l}2016 \\
2017 \\
\end{array}$ & menurun & menurun & menurun & menurun & sama & menurun & sama & sama & sama \\
\hline 15 & Gantole & 37.38 & 61.13 & 39.13 & 26.13 & & 34.00 & & & & $\begin{array}{l}2016 \\
2017\end{array}$ & menurun & menurun & menurun & menurun & sama & menurun & sama & sama & sama \\
\hline 16 & Gulat & 42.10 & 55.30 & 48.20 & 45.10 & 3.51 & 39.74 & & & & $\begin{array}{l}2016 \\
2017\end{array}$ & menurun & menurun & menurun & menurun & menurun & menurun & sama & sama & sama \\
\hline 17 & Judo & \begin{tabular}{|l|}
37.88 \\
37.92 \\
\end{tabular} & \begin{tabular}{|l|}
43.50 \\
1.75 \\
\end{tabular} & $\begin{array}{l}41.63 \\
47.83 \\
\end{array}$ & $\begin{array}{l}41.00 \\
37.25 \\
\end{array}$ & 3.88 & $\begin{array}{l}30.70 \\
30.86 \\
\end{array}$ & 8.92 & 35.84 & 32.07 & $\begin{array}{l}2016 \\
2017 \\
\end{array}$ & meningkat & menurun & meningkat & menurun & menurun & meningkat & meningkat & meningkat & meningkat \\
\hline 18 & Karate & \begin{tabular}{|l|}
47.00 \\
44.30 \\
\end{tabular} & \begin{tabular}{|l|}
51.50 \\
56.30 \\
\end{tabular} & $\begin{array}{l}47.00 \\
54.00\end{array}$ & $\begin{array}{l}31.50 \\
38.80 \\
\end{array}$ & & $\begin{array}{l}36.80 \\
41.50 \\
\end{array}$ & 6.40 & & & $\begin{array}{l}2016 \\
2017\end{array}$ & meningkat & meningkat & meningkat & meningkat & sama & meningkat & meningkat & sama & sama \\
\hline 19 & Kempo & 43.43 & 46.71 & 47.07 & 53.07 & 3.66 & 35.53 & & & & $\begin{array}{l}2016 \\
2017 \\
\end{array}$ & menurun & menurun & menurun & menurun & menurun & menurun & sama & sama & sama \\
\hline 20 & Tembak & 43.13 & 52.29 & 41.08 & 36.00 & 3.67 & 37.10 & & & & $\begin{array}{l}2016 \\
2017 \\
\end{array}$ & menurun & menurun & menurun & menurun & menurun & menurun & sama & sama & sama \\
\hline 21 & Paralayang & 36.60 & 33.60 & 19.00 & 24.00 & & 24.98 & & & & $\begin{array}{l}2016 \\
2017 \\
\end{array}$ & menurun & menurun & menurun & menurun & sama & menurun & sama & sama & sama \\
\hline 22 & Pencak Silat & \begin{tabular}{|l|}
39.60 \\
43.41 \\
\end{tabular} & \begin{tabular}{|l|}
48.08 \\
50.35 \\
\end{tabular} & $\begin{array}{l}34.75 \\
55.41 \\
\end{array}$ & $\begin{array}{l}38.17 \\
40.58 \\
\end{array}$ & & \begin{tabular}{|l|}
29.53 \\
44.04 \\
\end{tabular} & 6.36 & 30.58 & 28.40 & $\begin{array}{l}2016 \\
2017\end{array}$ & meningkat & meningkat & meningkat & meningkat & sama & meningkat & meningkat & meningkat & meningkat \\
\hline 23 & Renang & 49.88 & 48.33 & 37.50 & 39.92 & 11.42 & 34.31 & & & & $\begin{array}{l}2016 \\
2017\end{array}$ & menurun & menurun & menurun & menurun & menurun & menurun & sama & sama & sama \\
\hline 24 & Senam & \begin{tabular}{|l|}
55.06 \\
40.22 \\
\end{tabular} & \begin{tabular}{|l|}
46.00 \\
44.22 \\
\end{tabular} & $\begin{array}{l}39.88 \\
49.33 \\
\end{array}$ & \begin{tabular}{|l|}
37.25 \\
46.44 \\
\end{tabular} & 3.83 & \begin{tabular}{|l|}
32.23 \\
30.72 \\
\end{tabular} & 7.17 & 19.84 & 19.57 & $\begin{array}{l}2016 \\
2017 \\
\end{array}$ & meningkat & menurun & menurun & meningkat & menurun & menurun & meningkat & meningkat & meningkat \\
\hline 25 & Futsal & 40.6 & 48 & 52 & 35.2 & 3.5 & 36.13 & & & & \begin{tabular}{|l|}
2016 \\
2017 \\
\end{tabular} & meningkat & menurun & meningkat & menurun & menurun & menurun & meningkat & meningkat & meningkat \\
\hline
\end{tabular}




\begin{tabular}{|c|c|c|c|c|c|c|c|c|c|c|c|c|c|c|c|c|c|c|c|c|}
\hline 26 & Sepak Bola & 42.22 & 52.44 & 41.89 & 41.44 & 5.45 & 35.33 & & & & $\begin{array}{l}2016 \\
2017\end{array}$ & menurun & menurun & menurun & meningkat & menurun & menurun & meningkat & meningkat & meningkat \\
\hline 27 & $\begin{array}{l}\text { Sepak } \\
\text { Takraw }\end{array}$ & $\begin{array}{l}42.14 \\
38.44 \\
\end{array}$ & $\begin{array}{l}52.36 \\
50.00 \\
\end{array}$ & $\begin{array}{l}41.55 \\
40.00 \\
\end{array}$ & $\begin{array}{l}33.36 \\
34.00 \\
\end{array}$ & 3.54 & $\begin{array}{l}34.31 \\
32.15 \\
\end{array}$ & 6.67 & 26.70 & 27.95 & $\begin{array}{l}2016 \\
2017 \\
\end{array}$ & menurun & menurun & menurun & meningkat & menurun & menurun & meningkat & meningkat & meningkat \\
\hline 28 & Selam & $\begin{array}{l}39.56 \\
43.50 \\
\end{array}$ & $\begin{array}{l}48.18 \\
49.00 \\
\end{array}$ & $\begin{array}{l}31.82 \\
45.33 \\
\end{array}$ & $\begin{array}{l}34.82 \\
42.67 \\
\end{array}$ & 3.67 & $\begin{array}{l}30.25 \\
38.07 \\
\end{array}$ & 6.29 & 38.70 & 36.80 & $\begin{array}{l}2016 \\
2017 \\
\end{array}$ & meningkat & meningkat & meningkat & meningkat & menurun & meningkat & meningkat & meningkat & meningkat \\
\hline 29 & Taekwondo & 42.87 & 53.46 & 48.13 & 30.75 & 3.47 & 38.41 & & & & $\begin{array}{l}2016 \\
2017 \\
\end{array}$ & menurun & menurun & menurun & menurun & menurun & menurun & sama & sama & sama \\
\hline 30 & Tarung Drajat & $\begin{array}{l}42.55 \\
43.00 \\
\end{array}$ & $\begin{array}{l}57.30 \\
61.57 \\
\end{array}$ & $\begin{array}{l}49.90 \\
59.57 \\
\end{array}$ & $\begin{array}{l}54.80 \\
68.86 \\
\end{array}$ & & $\begin{array}{l}36.48 \\
40.21 \\
\end{array}$ & 6.14 & 38.94 & 37.50 & $\begin{array}{l}2016 \\
2017 \\
\end{array}$ & meningkat & meningkat & meningkat & meningkat & sama & meningkat & t meningkat & meningkat & meningkat \\
\hline 31 & \begin{tabular}{|l|}
$\begin{array}{l}\text { Tenis } \\
\text { Lapangan }\end{array}$ \\
\end{tabular} & $\begin{array}{l}40.06 \\
39.44 \\
\end{array}$ & $\begin{array}{l}53.89 \\
43.33 \\
\end{array}$ & $\begin{array}{l}20.44 \\
35.00 \\
\end{array}$ & \begin{tabular}{|l|}
13.78 \\
22.89 \\
\end{tabular} & 3.57 & $\begin{array}{l}26.26 \\
30.44 \\
\end{array}$ & 7.43 & & & $\begin{array}{l}2016 \\
2017 \\
\end{array}$ & menurun & menurun & meningkat & meningkat & menurun & meningkat & $t$ meningkat & sama & sama \\
\hline 32 & Tenis Meja & $\begin{array}{l}41.99 \\
32.17 \\
\end{array}$ & $\begin{array}{l}46.86 \\
42.00 \\
\end{array}$ & $\begin{array}{l}45.71 \\
40.00 \\
\end{array}$ & $\begin{array}{l}34.29 \\
27.33 \\
\end{array}$ & 3.80 & $\begin{array}{l}30.03 \\
23.50 \\
\end{array}$ & 7.93 & 27.78 & 22.46 & $\begin{array}{l}2016 \\
2017 \\
\end{array}$ & menurun & menurun & menurun & menurun & menurun & menurun & meningkat & meningkat & meningkat \\
\hline 33 & Tinju & $\begin{array}{l}43.91 \\
42.75 \\
\end{array}$ & 50.91 & $\begin{array}{l}39.55 \\
65.00 \\
5.00\end{array}$ & $\begin{array}{l}42.36 \\
43.88 \\
\end{array}$ & 9.16 & $\begin{array}{l}34.52 \\
43.64 \\
\end{array}$ & 7.13 & 42.36 & 40.49 & $\begin{array}{l}2016 \\
2017 \\
\end{array}$ & menurun & meningkat & meningkat & meningkat & menurun & meningkat & meningkat & meningkat & meningkat \\
\hline 34 & Wushu & $\begin{array}{l}41.20 \\
46.57 \\
\end{array}$ & $\begin{array}{l}53.00 \\
37.50 \\
\end{array}$ & $\begin{array}{l}50.40 \\
46.00 \\
\end{array}$ & $\begin{array}{l}46.30 \\
40.50 \\
\end{array}$ & 3.61 & $\begin{array}{l}28.93 \\
35.64 \\
\end{array}$ & 6.46 & 25.51 & 22.71 & $\begin{array}{l}2016 \\
2017 \\
\end{array}$ & meningkat & menurun & menurun & menurun & menurun & meningkat & meningkat & meningkat & meningkat \\
\hline 35 & Voli Pantai & $\begin{array}{l}40.88 \\
39.30 \\
\end{array}$ & $\begin{array}{l}73.75 \\
61.90 \\
\end{array}$ & $\begin{array}{l}42.50 \\
52.90 \\
\end{array}$ & $\begin{array}{l}29.00 \\
29.40 \\
\end{array}$ & 3.18 & $\begin{array}{l}40.18 \\
37.50 \\
\end{array}$ & 6.27 & 37.83 & 38.10 & $\begin{array}{l}2016 \\
2017 \\
\end{array}$ & menurun & menurun & meningkat & meningkat & menurun & menurun & meningkat & meningkat & meningkat \\
\hline 36 & Golft & 39.00 & 37.00 & 20.50 & 30.50 & & & & 22.90 & 21.25 & $\begin{array}{l}2016 \\
2017 \\
\end{array}$ & meningkat & meningkat & meningkat & meningkat & sama & sama & sama & meningkat & meningkat \\
\hline 37 & Softball & 41.61 & 49.61 & 42.61 & 20.17 & & 32.69 & 6.70 & 30.41 & 29.35 & $\begin{array}{l}2016 \\
2017 \\
\end{array}$ & meningkat & meningkat & meningkat & meningkat & sama & meningkat & meningkat & meningkat & meningkat \\
\hline 38 & Angkat Berat & 38.00 & 42.00 & 31.71 & 20.71 & & & & 27.87 & 24.66 & $\begin{array}{l}2016 \\
2017 \\
\end{array}$ & meningkat & meningkat & meningkat & meningkat & sama & sama & sama & meningkat & meningkat \\
\hline 39 & Sepatu Roda & 35.67 & 54.17 & 37.33 & 28.67 & 3.36 & 41.98 & & & & $\begin{array}{l}2016 \\
2017 \\
\end{array}$ & menurun & menurun & menurun & menurun & menurun & menurun & sama & sama & sama \\
\hline 40 & Panahan & $\begin{array}{l}37.93 \\
36.90 \\
\end{array}$ & $\begin{array}{l}44.71 \\
40.80 \\
\end{array}$ & $\begin{array}{l}25.50 \\
29.40 \\
\end{array}$ & $\begin{array}{l}25.64 \\
35.00 \\
\end{array}$ & & $\begin{array}{l}29.21 \\
29.54 \\
\end{array}$ & 7.78 & 29.96 & 25.60 & $\begin{array}{l}2016 \\
2017 \\
\end{array}$ & menurun & menurun & meningkat & meningkat & sama & meningkat & meningkat & meningkat & meningkat \\
\hline 41 & Panjat Tebing & $\begin{array}{l}39.96 \\
41.50 \\
\end{array}$ & $\begin{array}{l}53.83 \\
50.50 \\
\end{array}$ & $\begin{array}{l}47.00 \\
38.63 \\
\end{array}$ & $\begin{array}{l}33.75 \\
36.25 \\
\end{array}$ & & $\begin{array}{l}40.58 \\
36.41 \\
\end{array}$ & 4.49 & 39.01 & 39.31 & $\begin{array}{l}2016 \\
2017 \\
\end{array}$ & meningkat & menurun & menurun & meningkat & sama & menurun & meningkat & meningkat & meningkat \\
\hline
\end{tabular}

\section{Deskripsi dan Analisis Data}

Dari 41 cabor yang ada, merupakan data yang diambil dari hasil tes yang telah diselenggarakan Koni Surakarta. Data yang terkumpul merupakan data deskriptif yang kemudian dikonversi menjadi data kuantitatif dengan indeks penilaian yang telah ditentukan sesuai dengan pencapaian indikator dan subindikator pada tiap item tes seperti yang dapat dilihat di bawah ini.

\section{Anggar}

Dari hasil tes fisik cabang olahraga Anggar yang telah diselenggarakan pada tahun 2016 dan 2017, di tahun 2017 mengalami perubahan hasil pada beberapa item tes yang telah dilaksanakan :

$\begin{array}{lll}\text { Meningkat } & : & 5 \text { item tes } \\ \text { Menurun } & : & 4 \text { item tes } \\ \text { Sama } & : & 0 \text { item tes }\end{array}$

Kesimpulan dari data di atas, bahwa tes fisik pada cabang olahraga Anggar di tahun 2017 mengalami peningkatan.

\section{Aeromodeling}

Dari hasil tes fisik cabang olahraga Aeromodeling yang telah diselenggarakan pada tahun 2016 dan 2017, di tahun 2017 mengalami perubahan hasil pada beberapa item tes yang telah dilaksanakan :

$\begin{array}{lll}\text { Meningkat } & : & 4 \text { item tes } \\ \text { Menurun } & : & 5 \text { item tes } \\ \text { Sama } & : & 0 \text { item tes }\end{array}$

Kesimpulan dari data di atas, bahwa tes fisik pada cabang olahraga Aeromodeling di tahun 2017 mengalami penurunan. 


\section{PAPSI}

Dari hasil tes fisik cabang olahraga PAPSI yang telah diselenggarakan pada tahun 2016 dan 2017, di tahun 2017 mengalami perubahan hasil pada beberapa item tes yang telah dilaksanakan :

Meningkat : 1 item tes

Menurun : 4 item tes

Sama $\quad: \quad 4$ item tes

Kesimpulan dari data di atas, bahwa tes fisik pada cabang olahraga PAPSI di tahun 2017 mengalami penurunan.

\section{Atletik}

Dari hasil tes fisik cabang olahraga Atletik yang telah diselenggarakan pada tahun 2016 dan 2017, di tahun 2017 mengalami perubahan hasil pada beberapa item tes yang telah dilaksanakan :

Meningkat : 2 item tes

Menurun : 4 item tes

Sama $\quad: \quad 3$ item tes

Kesimpulan dari data di atas, bahwa tes fisik pada cabang olahraga Atletik di tahun 2017 mengalami penurunan.

\section{Balap Motor}

Dari hasil tes fisik cabang olahraga Balap Motor yang telah diselenggarakan pada tahun 2016 dan 2017, di tahun 2017 mengalami perubahan hasil pada beberapa item tes yang telah dilaksanakan :

Meningkat : 0 item tes

Menurun : 6 item tes

Sama $\quad: \quad 3$ item tes

Kesimpulan dari data di atas, bahwa tes fisik pada cabang olahraga Balap Motor di tahun 2017 mengalami penurunan, dikarenakan pada tahun 2017 cabang olahraga ini tidak ada.

\section{Balap Sepeda}

Dari hasil tes fisik cabang olahraga Balap Sepeda yang telah diselenggarakan pada tahun 2016 dan 2017, di tahun 2017 mengalami perubahan hasil pada beberapa item tes yang telah dilaksanakan :

Meningkat : 8 item tes

Menurun : 1 item tes

Sama : $\quad 0$ item tes

Kesimpulan dari data di atas, bahwa tes fisik pada cabang olahraga Balap Sepeda di tahun 2017 mengalami peningkatan. 


\section{Billiard}

Dari hasil tes fisik cabang olahraga Billiard yang telah diselenggarakan pada tahun 2016 dan 2017, di tahun 2017 mengalami perubahan hasil pada beberapa item tes yang telah dilaksanakan :

Meningkat : 0 item tes

Menurun : 6 item tes

Sama : 3 item tes

Kesimpulan dari data di atas, bahwa tes fisik pada cabang olahraga Billiard di tahun 2017 mengalami penurunan, dikarenakan pada tahun 2017 cabang olahraga ini tidak ada.

\section{Basket}

Dari hasil tes fisik cabang olahraga Basket yang telah diselenggarakan pada tahun 2016 dan 2017, di tahun 2017 mengalami perubahan hasil pada beberapa item tes yang telah dilaksanakan :

$\begin{array}{lll}\text { Meningkat } & : & 6 \text { item tes } \\ \text { Menurun } & : & 3 \text { item tes } \\ \text { Sama } & : & 0 \text { item tes }\end{array}$

Kesimpulan dari data di atas, bahwa tes fisik pada cabang olahraga Basket di tahun 2017 mengalami peningkatan.

\section{Bola Voley}

Dari hasil tes fisik cabang olahraga Bola Voley yang telah diselenggarakan pada tahun 2016 dan 2017, di tahun 2017 mengalami perubahan hasil pada beberapa item tes yang telah dilaksanakan :

$\begin{array}{lll}\text { Meningkat } & : & 0 \text { item tes } \\ \text { Menurun } & : & 6 \text { item tes } \\ \text { Sama } & : & 3 \text { item tes }\end{array}$

Kesimpulan dari data di atas, bahwa tes fisik pada cabang olahraga Bola Voley di tahun 2017 mengalami penurunan, dikarenakan pada tahun 2017 cabang olahraga ini tidak ada.

\section{Bridge}

Dari hasil tes fisik cabang olahraga Bridge yang telah diselenggarakan pada tahun 2016 dan 2017, di tahun 2017 mengalami perubahan hasil pada beberapa item tes yang telah dilaksanakan :

$\begin{array}{lll}\text { Meningkat } & : & 3 \text { item tes } \\ \text { Menurun } & : & 6 \text { item tes } \\ \text { Sama } & : & 0 \text { item tes }\end{array}$

Kesimpulan dari data di atas, bahwa tes fisik pada cabang olahraga Bridge di tahun 2017 mengalami penurunan. 


\section{Bulutangkis}

Dari hasil tes fisik cabang olahraga Bulutangkis yang telah diselenggarakan pada tahun 2016 dan 2017, di tahun 2017 mengalami perubahan hasil pada beberapa item tes yang telah dilaksanakan :

Meningkat : 0 item tes

Menurun : 6 item tes

Sama : 3 item tes

Kesimpulan dari data di atas, bahwa tes fisik pada cabang olahraga Bulutangkis di tahun 2017 mengalami penurunan, dikarenakan pada tahun 2017 cabang olahraga ini tidak ada.

\section{Catur}

Dari hasil tes fisik cabang olahraga Catur yang telah diselenggarakan pada tahun 2016 dan 2017, di tahun 2017 mengalami perubahan hasil pada beberapa item tes yang telah dilaksanakan :

$\begin{array}{lll}\text { Meningkat } & : & 8 \text { item tes } \\ \text { Menurun } & : & 1 \text { item tes } \\ \text { Sama } & : & 0 \text { item tes }\end{array}$

Kesimpulan dari data di atas, bahwa tes fisik pada cabang olahraga Catur di tahun 2017 mengalami peningkatan.

\section{Dansa}

Dari hasil tes fisik cabang olahraga Dansa yang telah diselenggarakan pada tahun 2016 dan 2017, di tahun 2017 mengalami perubahan hasil pada beberapa item tes yang telah dilaksanakan :

$\begin{array}{lll}\text { Meningkat } & : & 0 \text { item tes } \\ \text { Menurun } & : & 6 \text { item tes } \\ \text { Sama } & : & 3 \text { item tes }\end{array}$

Kesimpulan dari data di atas, bahwa tes fisik pada cabang olahraga Dansa di tahun 2017 mengalami penurunan, dikarenakan pada tahun 2017 cabang olahraga ini tidak ada.

\section{Drumband}

Dari hasil tes fisik cabang olahraga Drumband yang telah diselenggarakan pada tahun 2016 dan 2017, di tahun 2017 mengalami perubahan hasil pada beberapa item tes yang telah dilaksanakan :

$\begin{array}{lll}\text { Meningkat } & : & 0 \text { item tes } \\ \text { Menurun } & : & 5 \text { item tes } \\ \text { Sama } & : & 4 \text { item tes }\end{array}$

Kesimpulan dari data di atas, bahwa tes fisik pada cabang olahraga Drumband di tahun 2017 mengalami penurunan, dikarenakan pada tahun 2017 cabang olahraga ini tidak ada. 


\section{Gantole}

Dari hasil tes fisik cabang olahraga Gantole yang telah diselenggarakan pada tahun 2016 dan 2017, di tahun 2017 mengalami perubahan hasil pada beberapa item tes yang telah dilaksanakan :

Meningkat : 0 item tes

Menurun : 5 item tes

Sama $\quad: \quad 4$ item tes

Kesimpulan dari data di atas, bahwa tes fisik pada cabang olahraga Gantole di tahun 2017 mengalami penurunan, dikarenakan pada tahun 2017 cabang olahraga ini tidak ada.

\section{Gulat}

Dari hasil tes fisik cabang olahraga Gulat yang telah diselenggarakan pada tahun 2016 dan 2017, di tahun 2017 mengalami perubahan hasil pada beberapa item tes yang telah dilaksanakan :

Meningkat : 0 item tes

Menurun : 6 item tes

Sama $\quad: \quad 3$ item tes

Kesimpulan dari data di atas, bahwa tes fisik pada cabang olahraga Gulat di tahun 2017 mengalami penurunan, dikarenakan pada tahun 2017 cabang olahraga ini tidak ada.

\section{Judo}

Dari hasil tes fisik cabang olahraga Judo yang telah diselenggarakan pada tahun 2016 dan 2017, di tahun 2017 mengalami perubahan hasil pada beberapa item tes yang telah dilaksanakan :

$\begin{array}{lll}\text { Meningkat } & : & 6 \text { item tes } \\ \text { Menurun } & : & 3 \text { item tes } \\ \text { Sama } & : & 0 \text { item tes }\end{array}$

Kesimpulan dari data di atas, bahwa tes fisik pada cabang olahraga Judo di tahun 2017 mengalami peningkatan.

\section{Karate}

Dari hasil tes fisik cabang olahraga Karate yang telah diselenggarakan pada tahun 2016 dan 2017, di tahun 2017 mengalami perubahan hasil pada beberapa item tes yang telah dilaksanakan :

Meningkat : 6 item tes

Menurun : 0 item tes

Sama : 3 item tes

Kesimpulan dari data di atas, bahwa tes fisik pada cabang olahraga Karate di tahun 2017 mengalami peningkatan. 


\section{Kempo}

Dari hasil tes fisik cabang olahraga Kempo yang telah diselenggarakan pada tahun 2016 dan 2017, di tahun 2017 mengalami perubahan hasil pada beberapa item tes yang telah dilaksanakan :

Meningkat : 0 item tes

Menurun : 6 item tes

Sama $\quad: \quad 3$ item tes

Kesimpulan dari data di atas, bahwa tes fisik pada cabang olahraga Kempo di tahun 2017 mengalami penurunan, dikarenakan pada tahun 2017 cabang olahraga ini tidak ada.

\section{Tembak}

Dari hasil tes fisik cabang olahraga Tembak yang telah diselenggarakan pada tahun 2016 dan 2017, di tahun 2017 mengalami perubahan hasil pada beberapa item tes yang telah dilaksanakan :

$\begin{array}{lll}\text { Meningkat } & : & 0 \text { item tes } \\ \text { Menurun } & : & 6 \text { item tes } \\ \text { Sama } & : & 3 \text { item tes }\end{array}$

Kesimpulan dari data di atas, bahwa tes fisik pada cabang olahraga Tembak di tahun 2017 mengalami penurunan, dikarenakan pada tahun 2017 cabang olahraga ini tidak ada.

\section{Paralayang}

Dari hasil tes fisik cabang olahraga Paralayang yang telah diselenggarakan pada tahun 2016 dan 2017, di tahun 2017 mengalami perubahan hasil pada beberapa item tes yang telah dilaksanakan :

$\begin{array}{lll}\text { Meningkat } & : & 0 \text { item tes } \\ \text { Menurun } & : & 5 \text { item tes } \\ \text { Sama } & : & 4 \text { item tes }\end{array}$

Kesimpulan dari data di atas, bahwa tes fisik pada cabang olahraga Paralayang di tahun 2017 mengalami penurunan.

\section{Pencak Silat}

Dari hasil tes fisik cabang olahraga Pencak silat yang telah diselenggarakan pada tahun 2016 dan 2017, di tahun 2017 mengalami perubahan hasil pada beberapa item tes yang telah dilaksanakan :

Meningkat : 8 item tes

Menurun : 0 item tes

Sama : $\quad 1$ item tes

Kesimpulan dari data di atas, bahwa tes fisik pada cabang olahraga Pencak Silat di tahun 2017 mengalami peningkatan. Dikarenakan hasil dari tiap tes fisik yang dilakukan atlet hampir semuanya meningkat dari tahun 2016. 


\section{Renang}

Dari hasil tes fisik cabang olahraga Renang yang telah diselenggarakan pada tahun 2016 dan 2017, di tahun 2017 mengalami perubahan hasil pada beberapa item tes yang telah dilaksanakan :

Meningkat : 0 item tes

Menurun : 6 item tes

Sama : 3 item tes

Kesimpulan dari data di atas, bahwa tes fisik pada cabang olahraga Renang di tahun 2017 mengalami penurunan.

\section{Senam}

Dari hasil tes fisik cabang olahraga Senam yang telah diselenggarakan pada tahun 2016 dan 2017, di tahun 2017 mengalami perubahan hasil pada beberapa item tes yang telah dilaksanakan :

Meningkat : 5 item tes

Menurun : 4 item tes

Sama : $\quad 0$ item tes

Kesimpulan dari data di atas, bahwa tes fisik pada cabang olahraga Senam di tahun 2017 mengalami peningkatan.

\section{Futsal}

Dari hasil tes fisik cabang olahraga Futsal yang telah diselenggarakan pada tahun 2016 dan 2017, di tahun 2017 mengalami perubahan hasil pada beberapa item tes yang telah dilaksanakan :

$\begin{array}{lll}\text { Meningkat } & : & 5 \text { item tes } \\ \text { Menurun } & : & 4 \text { item tes } \\ \text { Sama } & : & 0 \text { item tes }\end{array}$

Kesimpulan dari data di atas, bahwa tes fisik pada cabang olahraga Futsal di tahun 2017 mengalami peningkatan.

\section{Sepak Bola}

Dari hasil tes fisik cabang olahraga Sepak Bola yang telah diselenggarakan pada tahun 2016 dan 2017, di tahun 2017 mengalami perubahan hasil pada beberapa item tes yang telah dilaksanakan :

$\begin{array}{lll}\text { Meningkat } & : & 4 \text { item tes } \\ \text { Menurun } & : & 5 \text { item tes } \\ \text { Sama } & : & 0 \text { item tes }\end{array}$

Kesimpulan dari data di atas, bahwa tes fisik pada cabang olahraga Sepak Bola di tahun 2017 mengalami penurunan. 


\section{Sepak Takraw}

Dari hasil tes fisik cabang olahraga Renang yang telah diselenggarakan pada tahun 2016 dan 2017, di tahun 2017 mengalami perubahan hasil pada beberapa item tes yang telah dilaksanakan :

Meningkat : 4 item tes

Menurun : 5 item tes

Sama : 0 item tes

Kesimpulan dari data di atas, bahwa tes fisik pada cabang olahraga Renang di tahun 2017 mengalami penurunan.

\section{Selam}

Dari hasil tes fisik cabang olahraga Selam yang telah diselenggarakan pada tahun 2016 dan 2017, di tahun 2017 mengalami perubahan hasil pada beberapa item tes yang telah dilaksanakan :

Meningkat : 8 item tes

Menurun : 1 item tes

Sama : $\quad 0$ item tes

Kesimpulan dari data di atas, bahwa tes fisik pada cabang olahraga Selam di tahun 2017 mengalami peningkatan.

\section{Taekwondo}

Dari hasil tes fisik cabang olahraga Taekwondo yang telah diselenggarakan pada tahun 2016 dan 2017, di tahun 2017 mengalami perubahan hasil pada beberapa item tes yang telah dilaksanakan :

Meningkat : 0 item tes

Menurun : 6 item tes

Sama $\quad: \quad 3$ item tes

Kesimpulan dari data di atas, bahwa tes fisik pada cabang olahraga Taekwondo di tahun 2017 mengalami penurunan.

\section{Tarung Drajat}

Dari hasil tes fisik cabang olahraga Tarung Drajat yang telah diselenggarakan pada tahun 2016 dan 2017, di tahun 2017 mengalami perubahan hasil pada beberapa item tes yang telah dilaksanakan :

Meningkat : 0 item tes

Menurun : 8 item tes

Sama : $\quad 1$ item tes

Kesimpulan dari data di atas, bahwa tes fisik pada cabang olahraga Tarung Drajat di tahun 2017 mengalami penurunan. 


\section{Tenis Lapangan}

Dari hasil tes fisik cabang olahraga Tenis Lapangan yang telah diselenggarakan pada tahun 2016 dan 2017, di tahun 2017 mengalami perubahan hasil pada beberapa item tes yang telah dilaksanakan :

Meningkat : 4 item tes

Menurun : 3 item tes

Sama $\quad: \quad 2$ item tes

Kesimpulan dari data di atas, bahwa tes fisik pada cabang olahraga Tenis Lapangan di tahun 2017 mengalami peningkatan.

\section{Tenis Meja}

Dari hasil tes fisik cabang olahraga Tenis Meja yang telah diselenggarakan pada tahun 2016 dan 2017, di tahun 2017 mengalami perubahan hasil pada beberapa item tes yang telah dilaksanakan :

Meningkat : 0 item tes

Menurun : 6 item tes

Sama $\quad: \quad 3$ item tes

Kesimpulan dari data di atas, bahwa tes fisik pada cabang olahraga Tenis Meja di tahun 2017 mengalami penurunan.

\section{Tinju}

Dari hasil tes fisik cabang olahraga Tinju yang telah diselenggarakan pada tahun 2016 dan 2017, di tahun 2017 mengalami perubahan hasil pada beberapa item tes yang telah dilaksanakan :

Meningkat : 7 item tes

Menurun : 2 item tes

Sama : 0 item tes

Kesimpulan dari data di atas, bahwa tes fisik pada cabang olahraga Tinju di tahun 2017 mengalami peningkatan.

\section{Wushu}

Dari hasil tes fisik cabang olahraga Wushu yang telah diselenggarakan pada tahun 2016 dan 2017, di tahun 2017 mengalami perubahan hasil pada beberapa item tes yang telah dilaksanakan :

Meningkat : 5 item tes

Menurun : 4 item tes

Sama : 0 item tes

Kesimpulan dari data di atas, bahwa tes fisik pada cabang olahraga Wushu di tahun 2017 mengalami peningkatan. 


\section{Voli Pantai}

Dari hasil tes fisik cabang olahraga Voli Pantai yang telah diselenggarakan pada tahun 2016 dan 2017, di tahun 2017 mengalami perubahan hasil pada beberapa item tes yang telah dilaksanakan :

Meningkat : 0 item tes

Menurun : 6 item tes

Sama : 3 item tes

Kesimpulan dari data di atas, bahwa tes fisik pada cabang olahraga Voli Pantai di tahun 2017 mengalami penurunan.

\section{Golf}

Dari hasil tes fisik cabang olahraga Gofl yang telah diselenggarakan pada tahun 2016 dan 2017, di tahun 2017 mengalami perubahan hasil pada beberapa item tes yang telah dilaksanakan :

Meningkat : 5 item tes

Menurun : 4 item tes

Sama : 0 item tes

Kesimpulan dari data di atas, bahwa tes fisik pada cabang olahraga Golf di tahun 2017 mengalami peningkatan.

\section{Softball}

Dari hasil tes fisik cabang olahraga Softball yang telah diselenggarakan pada tahun 2016 dan 2017, di tahun 2017 mengalami perubahan hasil pada beberapa item tes yang telah dilaksanakan :

$\begin{array}{lll}\text { Meningkat } & : & 6 \text { item tes } \\ \text { Menurun } & : & 0 \text { item tes } \\ \text { Sama } & : & 3 \text { item tes }\end{array}$

Kesimpulan dari data di atas, bahwa tes fisik pada cabang olahraga Softball di tahun 2017 mengalami peningkatan.

\section{Angkat Berat}

Dari hasil tes fisik cabang olahraga Angkat Berat yang telah diselenggarakan pada tahun 2016 dan 2017, di tahun 2017 mengalami perubahan hasil pada beberapa item tes yang telah dilaksanakan :

Meningkat : 8 item tes

Menurun : 0 item tes

Sama : 3 item tes

Kesimpulan dari data di atas, bahwa tes fisik pada cabang olahraga Angkat Berat di tahun 2017 mengalami peningkatan. 


\section{Sepatu Roda}

Dari hasil tes fisik cabang olahraga Sepatu Roda yang telah diselenggarakan pada tahun 2016 dan 2017, di tahun 2017 mengalami perubahan hasil pada beberapa item tes yang telah dilaksanakan :

$\begin{array}{lll}\text { Meningkat } & : & 0 \text { item tes } \\ \text { Menurun } & : & 6 \text { item tes } \\ \text { Sama } & : & 3 \text { item tes }\end{array}$

Kesimpulan dari data di atas, bahwa tes fisik pada cabang olahraga Sepatu Roda di tahun 2017 mengalami penurunan. Dikarenakan 6 item tes

\section{Panahan}

Dari hasil tes fisik cabang olahraga Panahan yang telah diselenggarakan pada tahun 2016 dan 2017, di tahun 2017 mengalami perubahan hasil pada beberapa item tes yang telah dilaksanakan :

$\begin{array}{lll}\text { Meningkat } & : & 6 \text { item tes } \\ \text { Menurun } & : & 2 \text { item tes } \\ \text { Sama } & : & 1 \text { item tes }\end{array}$

Kesimpulan dari data di atas, bahwa tes fisik pada cabang olahraga Panahan di tahun 2017 mengalami peningkatan. Dikarenakan terdapat 6 item tes yang meningkat dibandingkan pada tahun 2016.

\section{Panjat Tebing}

Dari hasil tes fisik cabang olahraga Panjat Tebing yang telah diselenggarakan pada tahun 2016 dan 2017, di tahun 2017 mengalami perubahan hasil pada beberapa item tes yang telah dilaksanakan :

$\begin{array}{lll}\text { Meningkat } & : & 5 \text { item tes } \\ \text { Menurun } & : & 3 \text { item tes } \\ \text { Sama } & : & 1 \text { item tes }\end{array}$

Kesimpulan dari data di atas, bahwa tes fisik pada cabang olahraga Panjat Tebing di tahun 2017 mengalami peningkatan. Dikarenakan terdapat 5 item tes yang meningkat dari tahun 2016.

\section{Kesimpulan}

Peningkatan kondisi fisik dalam pembinaan atlet berprestasi sangat diperlukan untuk mengevaluasi sebuah program latihan, apakah atlet mengalami peningkatan atau penurunan. Apabila atlet mengalami peningkatan maka program latihan yang diterapkan mencapai target yang sudah di tentukan dan apabila mengalami penurunan bisa dikatakan program latihan kurang menyasar dan tidak sesuai dengan kondisi dari atlet. Dari 41 cabang olahraga yang di naungi KONI Kota Surakarta secara garis besar peningkatan kondisi fisik dalam kurun waktu satu tahun antara tahun 2016 sampai 2017 adalah, 22 cabor(53,6 \%) mengalami penurunan kondisi fisik atlet dan 19 cabor(46,4\%) mengalami peningkatan kondisi fisik. 
Kesimpulan umum kondisi atlet Porprov kota Surakarta dari tahun 2016 sampai 2017 mengalami penurunan, penurunan kondisi fisik tersebut di sebabkan beberapa faktor antara lain : 1. Penerapan program latihan yang tidak sesuai dengan sport science. 2. Asupan gizi yang tidak memadai. 3. Kondisi psikologi atlet yang kurang termanajemen dengan baik. Dengan adanya evaluasi kondisi fisik atlet diharapkan perhatian dari masing-masing pengurus cabang olahraga untuk memperbaiki dan meningkatkan program latihan, memanejemen pengelolaan tim pelatih serta memperhatikan masing-masing atlet secara individu, apa yang menjadi kedala dalam latihan sehingga target prestasi yang sudah di canangkan tercapai bahkan terlampaui.

\section{Daftar pustaka :}

Baumgartner, T.A dan Jackson, A.S, 1995: Measurement for Evaluation in Physical Education and Exercise Science, Fifth Edition, Dubuque, Iowa, Brown and Benchmark.

Johnson, B.L and Nelson, J.K, 1996: Practical Measurements for Evaluation Physical Education, New York, MacMillan Publishing Company

Kirkendall, D.R., Gruber, J.J., dan Johnson, R.E., 1980: Measurement and Evaluation for Physical Educators, Second Edition, Champaign, Human Kinetics Publishers, Inc.

R. Lumintuarso, 2001. Pemandu Bakat Atletik. PASI

Sajoto M, 1988: Pembinaan Kondisi Fisik Dalam Olahraga, Jakarta, Dirjen Dikti.

Suharno, H.P, 1992: Metode Pelatihan, Materi Coaching Clinic PBVSI 